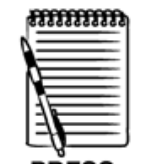

PRESS

RELEASE

\title{
Translocation of Crohn's disease Escherichia coli across M-cells: contrasting effects of soluble plant fibres and emulsifiers
}

\author{
Carol L Roberts, ${ }^{1}$ Åsa V Keita, ${ }^{2}$ Sylvia H Duncan, ${ }^{3}$ Niamh O'Kennedy, ${ }^{4}$ \\ Johan D Söderholm, ${ }^{2}$ Jonathan M Rhodes, ${ }^{1}$ Barry J Campbell ${ }^{1}$
}

\begin{abstract}
- Additional materials are published online only. To view these files please visit the journal online (http://gut.bmj. com).

${ }^{1}$ Gastroenterology Research Unit, School of Clinical Sciences, University of Liverpool, Liverpool, UK

${ }^{2}$ Clinical and Experimental Medicine, Division of Surgery, Faculty of Health Sciences, Linköping University, Linköping, Sweden

${ }^{3}$ The Microbial Ecology Group, The Rowett Institute of Nutrition and Health, University of Aberdeen, Bucksburn, UK ${ }^{4}$ Provexis Plc, c/o Rowett Institute of Nutrition and Health, UK
\end{abstract}

\section{Correspondence to} Dr Barry J Campbell, Gastroenterology Research Unit, University School of Clinical Sciences, Crown Street, Liverpool L69 3GE, UK; b.j.campbell@liv.ac.uk

Revised 28 May 2010 Accepted 1 June 2010

\section{(2) UNLOCK:1}

This paper is freely available online under the BMJ Journals unlocked scheme, see http:// gut.bmj.com/site/about/ unlocked.xhtml

\begin{abstract}
Background Crohn's disease is common in developed nations where the typical diet is low in fibre and high in processed food. Primary lesions overlie Peyer's patches and colonic lymphoid follicles where bacterial invasion through M-cells occurs. We have assessed the effect of soluble non-starch polysaccharide (NSP) and food emulsifiers on translocation of Escherichia coli across M-cells.
\end{abstract}

Methods To assess effects of soluble plant fibres and food emulsifiers on translocation of mucosa-associated E coli isolates from Crohn's disease patients and from non-Crohn's controls, we used M-cell monolayers, generated by co-culture of Caco2-cl1 and Raji B cells, and human Peyer's patches mounted in Ussing chambers.

Results $E$ coli translocation increased across M-cells compared to parent Caco2-cl1 monocultures; 15.8-fold (IQR 6.2-32.0) for Crohn's disease $E$ coli $(\mathrm{N}=8)$ and 6.7-fold (IOR 3.7-21.0) for control isolates ( $N=5$ ). Electron microscopy confirmed $E$ coli within M-cells. Plantain and broccoli NSP markedly reduced $E$ coli translocation across M-cells at $5 \mathrm{mg} / \mathrm{ml}$ (range 45.3-82.6\% inhibition, $\mathrm{p}<0.01$ ); apple and leek NSP had no significant effect. Polysorbate-80, 0.01\% vol/vol, increased $E$ coli translocation through Caco2-cl1 monolayers 59-fold $(p<0.05)$ and, at higher concentrations, increased translocation across M-cells. Similarly, E coli translocation across human Peyer's patches was reduced $45 \pm 7 \%$ by soluble plantain NSP $(5 \mathrm{mg} / \mathrm{ml})$ and increased 2-fold by polysorbate-80 $(0.1 \%$ $\mathrm{vol} / \mathrm{voll}$.

Conclusions Translocation of $E$ coli across M-cells is reduced by soluble plant fibres, particularly plantain and broccoli, but increased by the emulsifier Polysorbate-80. These effects occur at relevant concentrations and may contribute to the impact of dietary factors on Crohn's disease pathogenesis.

\section{INTRODUCTION}

Crohn's disease results from an interaction between genetic and environmental factors. The genetic factors include changes in genes that affect handling of bacteria by the innate immune system, regulation of the immune response, or the mucosal barrier ${ }^{1}$ but the environmental factors, aside from smoking, ${ }^{2}$ are poorly understood. There are marked geographical variations in Crohn's incidence, with lower prevalence in underdeveloped countries, and a rapid recent rise in Japan that has parallelled the

\section{Significance of the study}

What is known already about this subject?

- Enteric bacteria play an important role in the pathogenesis of inflammatory bowel disease.

- Earliest lesions in Crohn's disease overlie Peyer's patches and lymphoid follicles.

- Bacterial invasion of the gut epithelium usually occurs initially through specialised M (microfold) epithelial cells.

- The incidence of Crohn's disease has been increasing and diet is believed to be linked to its higher prevalence in industrialised parts of the world.

\section{What are the new findings?}

- The translocation of Crohn's disease mucosal Escherichia coli isolates across M-cells and Peyer's patches is inhibited by the presence of certain soluble plant fibres but increased in the presence of low concentrations of an emulsifier that is commonly used in processed foods.

How might it impact on clinical practice in the foreseeable future?

- Intervention studies are needed to assess the effects of dietary changes in soluble plant fibre and emulsifier intake on Crohn's disease activity.

introduction of a 'Western diet'. ${ }^{3}$ Moreover, clinical remission can be achieved by dietary interventions such as the use of specialised enteral feeds. ${ }^{4}$ It is therefore a plausible hypothesis that dietary factors may have either harmful or protective roles in Crohn's pathogenesis as a consequence of their effects on the interaction between the host epithelia and intestinal microbiota.

Increased numbers of $E$ coli have been found in association with Crohn's mucosa by several independent groups. ${ }^{5}$ They have also been found in association with colorectal cancer. ${ }^{67}$ Many of the isolated strains associated with Crohn's disease fit the new pathovar designated adherent, invasive $E$ coli (AIEC), ${ }^{8}$ as defined by their ability to adhere to, and invade intestinal epithelial cell lines in vitro (eg, I-407 and Caco2), ${ }^{6} 9$ and to survive and replicate intracellularly within macrophages without inducing host cell death. ${ }^{10}{ }^{11}$ Crohn's $E$ coli also cause interleukin 8 (IL-8) release from intestinal epithelial cells, ${ }^{12}$ and induce granuloma formation after internalisation by cultured macrophages. ${ }^{13}$ Despite considerable evidence of the presence of E coli within Crohn's tissue, particularly within 
macrophages and giant cells, ${ }^{14}{ }^{15}$ they have not been shown within the intestinal epithelial cells. The early aphthoid lesions of Crohn's usually overlie Peyer's patches (PP) in the distal small intestine and the equivalent but smaller lymphoid follicles in the colon. ${ }^{16} 17$ The 'dome' epithelium that overlies PP and lymphoid follicles, also denoted follicle-associated epithelium (FAE), is the location of 'membranous' or 'microfold' cells (M-cells), ${ }^{18}$ specialised epithelial cells that account for about $5-10 \%$ of the FAE. They internalise macromolecules and microorganisms, and deliver them to the underlying lymphoid tissue, providing a portal from which an immune response can be mounted. ${ }^{19}$ They also serve as a portal of entry for bona fide pathogens, such as Mycobacteria, ${ }^{20}$ Listeria, Salmonella, Shigella ${ }^{21}$ and Vibrio cholerae. $^{22} 23$ Since the initial lesions observed in Crohn's occur at PP and lymphoid follicles it seems likely that Crohn's mucosaassociated E coli, like Salmonella and Shigella, are translocated by $\mathrm{M}$-cells and subsequently delivered to the underlying macrophages.

We have previously shown that the adhesion to, and invasion by Crohn's and colon cancer mucosa-associated $E$ coli of, intestinal epithelial cells is inhibited by soluble plantain (green banana) fibre at concentrations that are potentially achievable in vivo. ${ }^{6}$ It is interesting that parts of the world such as Africa, India and Central America where plantains form an important part of the staple diet have low rates for inflammatory bowel disease and colon cancer. We have therefore now tested the ability of soluble plant fibres, such as those found in plantain, to block translocation of Crohn's E coli across M-cells in vitro.

Intestinal permeability is increased in patients with Crohn's disease and in their unaffected relatives. Although some of this increased permeability may be genetically determined it is also possible that environmental factors may be involved. ${ }^{24}$ The increase in the incidence of Crohn's disease seen in recent years in Japan correlates with increased fat intake. ${ }^{25}$ Although the fat itself may be harmful, it is also possible that increased consumption of emulsifiers contained in processed fatty foods could be a factor. Emulsifiers are detergents and, although permitted food emulsifiers are probably largely broken down during the digestive process, there has been relatively little investigation of their possible effects on intestinal permeability although it is well recognised that natural detergents in the form of bile acids can increase intestinal permeability ${ }^{26}$ and non-ionic detergents have been shown to increase permeability across Caco2 intestinal epithelial cell monolayers. ${ }^{27}$

In this study, Crohn's mucosa-associated $E$ coli are shown to be translocated across Caco2-cl1-derived M-cells to a much greater extent than across monolayers formed from parent Caco2-cl1 cells, which was also confirmed in ex vivo human ileum tissues of FAE and villus epithelium (VE), respectively. Transcellular translocation was confirmed by transmission electron microscopy (TEM) in M-cells, but could not be observed in Caco2-cl1 cell monolayers. Translocation is inhibited by the presence of soluble plant fibres, including plantain and broccoli. Polysorbate-80, at concentrations that might occur in the distal ileum if $7 \%$ of ingested polysorbate survives digestion, causes increased translocation across parent $\mathrm{Caco} 2-\mathrm{cl} 1$ cells but not across M-cells.

\section{MATERIAL AND METHODS}

\section{Bacterial strains and growth conditions}

E coli included strains previously isolated from colonic mucosal biopsies of six patients with Crohn's disease (HM95, HM154, HM413, HM419, HM580, HM605 and HM615) ${ }^{6}$ and the adherent, invasive ileal Crohn's strain, LF82. ${ }^{9}$ All our Crohn's colonic isolates were shown to meet current criteria for designation as AIEC. ${ }^{8}$ Five $E$ coli from patients without Crohn's disease were included as controls (HM454 and HM456, both from a patient with sporadic polyposis; HM463 from a patient with haemorrhoids; HM484 and HM488, both from patients with irritable bowel syndrome, ${ }^{6}$ along with non-pathogenic $E$ coli reference strains K12, XL-1blue and probiotic Nissle 1917. Salmonella typhimurium LT2 and Shigella sonnei were obtained from Dr Craig Winstanley, School of Infection \& Host Defence, University of Liverpool).

Isolates were cultured on Luria-Bertani (LB) agar with overnight incubation in air at $37^{\circ} \mathrm{C}$. Prior to infection of cultured epithelial cells, bacteria were washed three times, re-suspended in sterile phosphate-buffered saline (PBS) and adjusted to an $\mathrm{OD}_{550 \mathrm{~nm}}$ of 0.825 (equating to $1 \times 10^{9} \mathrm{CFU} / \mathrm{ml}$ ).

Crohn's E coli HM615, selected due to its sensitivity to ampicillin and possession of adherent, invasive characteristics, was transformed with a plasmid carrying the enhanced green fluorescent protein (egfp) gene (pEGFP; BD Biosciences-Clontech, Mountain View, USA), without alteration of strain-specific characteristics, ${ }^{6} 1112$ and was used in experiments examining bacterial translocation across ex vivo human FAE and VE.

\section{Dietary factors}

Non-starch polysaccharide (NSP) preparations from plant-based soluble dietary fibre were provided by Provexis Plc (Windsor, UK). Plantain, the banana family (Musa) member that is usually cooked as a vegetable, was selected as it had previously been found to inhibit mucosa-associated $E$ coli adhesion to epithelial cells in vitro. ${ }^{6}$ Plantain NSP consists of a complex mix of carbohydrates (see Supplementary document S1). Concentrations were chosen based on preliminary studies of inhibition of bacterial haemagglutination, inhibition of attachment to, and invasion of intestinal cells, ${ }^{6}$ and were within the range of intraluminal concentrations that would be readily achievable with dietary supplementation.

In addition, broccoli, leek and apple were selected to represent a range of common monocotyledon and dicotyledon sources of dietary soluble fibre. Common food emulsifiers used in the processed food industry, polysorbate- 60 and polysorbate-80, were obtained from Sigma-Aldrich (Poole, UK). Polysorbate-80, has been shown to integrate within cell membranes, ${ }^{28}$ altering their microviscosity. ${ }^{29}$

\section{Cell culture}

The human colorectal adenocarcinoma cell-line Caco2-cl1 kindly provided by Dr Elisabet Gullberg (University Hospital Linköping, Sweden) was originally obtained from Dr Maria Rescigno (European Institute of Oncology, Milan, Italy). ${ }^{30}$ Caco2-c11 were grown and maintained in Dulbecco's modified Eagle's medium (DMEM) supplemented with $10 \% \mathrm{vol} / \mathrm{vol}$ fetal bovine serum (FBS), $4 \mathrm{mM}$ L-glutamine, $100 \mathrm{U} / \mathrm{ml}$ penicillin and $100 \mu \mathrm{g} / \mathrm{ml}$ streptomycin. The human Burkitt's lymphoma cell-line Raji B (ECACC 85011429), obtained from the European Collection of Animal Cell Culture (Public Health Laboratory Service; Wiltshire, UK), was maintained in RPMI-1640 medium supplemented with 10\% FBS, $8 \mathrm{mM}$ L-glutamine, $100 \mathrm{U} / \mathrm{ml}$ penicillin and $100 \mu \mathrm{g} / \mathrm{ml}$ streptomycin. Raji B cells were seeded at $3 \times 10^{5} /$ $\mathrm{ml}$ and every third day cell suspensions were allowed to settle: Two thirds of the media was replaced with fresh culture media. Every ninth day, cells were split 1:3.

All cells were maintained at $37^{\circ} \mathrm{C}$ with $5 \% \mathrm{CO}_{2}$ in a humidified atmosphere. Culture medium and supplements were supplied by Sigma-Aldrich excepting FBS (Invitrogen; Paisley, UK). 


\section{Generation of M-cells}

The apical face of $12 \mathrm{~mm}$ Transwell cell culture inserts with a polycarbonate membrane (Millicell-PCF $3 \mu \mathrm{m}$ pore size; Millipore Ltd; Watford, UK) were each coated with $15 \mu \mathrm{g}$ Matrigel basement membrane matrix (in $300 \mu \mathrm{l}$ ice-cold DMEM without phenol red) per membrane. Coated membranes were left to gel for $1 \mathrm{~h}$ at room temperature in a sterile environment, followed by two $0.5 \mathrm{ml}$ washes in DMEM without supplements. Caco2-cl1 were passaged, re-suspended in supplemented DMEM and $5 \times 10^{5}$ cells added to each Transwell (apical side). Supplemented DMEM (2 ml) was added to each basal compartment. Importantly, the apical medium was changed every day and the basal media on every other day. Cells were maintained for 14-18 days, until the trans-epithelial electrical resistance (TEER), measured using an EVOM epithelial voltohmmeter (World Precision Instruments, Stevenage, UK), was in excess of $600 \Omega$ per Transwell (equivalent to $300 \Omega \mathrm{cm}^{2}$ tissue monolayer). On the day of co-culture, Raji B cells were harvested, re-suspended in complete DMEM and $5 \times 10^{5}$ cells added to the basal Transwell compartment. Importantly, following co-culture, both the apical and basal media were changed each day, with care being taken not to disturb the Raji B cells. Co-cultures were maintained for 4-6 days, until M-cells were generated. Parallel Caco2-cl1 monocultures (without Raji B cells in the basal compartment) were also generated on Transwell inserts and maintained as per M-cells. TEER was measured throughout to monitor successful monolayer generation. Translocation of Salmonella and Shigella was used to confirm successful generation of $\mathrm{M}$-cells in vitro.

\section{Bacterial translocation across M-cells}

For all M-cell and Caco2-cl1 monoculture translocation experiments, DMEM medium was prepared with $10 \% \mathrm{FBS}$ and $4 \mathrm{mM}$ L-glutamine only (ie, without anti-microbial agents). Confluent monolayers were infected (from $0-4 \mathrm{~h}$ ) with $1 \times 10^{7} \mathrm{E}$ coli (a multiplicity of infection (MOI) 10:1) applied to the apical Transwell compartment (filter area $0.6 \mathrm{~cm}^{2}$ ). After infection, the basolateral medium was harvested and bacteria enumerated following overnight culture on LB agar plates incubated at $37^{\circ} \mathrm{C}$ in air. Colony forming units (CFU) of viable bacteria were quantified and data expressed as translocated CFU per $\mathrm{cm}^{2}$ filter.

For studies examining the effect of soluble dietary fibres, fresh DMEM $(0.5 \mathrm{ml})$ containing $0-50 \mathrm{mg} / \mathrm{ml} \mathrm{NSP}$, either from apple, broccoli, leek or plantain, was applied to the apical aspect of the cells for $30 \mathrm{~min}$ at $37^{\circ} \mathrm{C}$. Two millilitres of fresh DMEM was placed in the basolateral compartment. Cell monolayers were then infected with $1 \times 10^{7} \mathrm{E}$ coli applied to the apical Transwell compartment. After $4 \mathrm{~h}$, the basolateral medium was harvested and translocated bacteria quantified as described above.

For studies examining the effect of food emulsifiers on bacterial translocation through $\mathrm{M}$-cells and Caco2-cl1 monocultures, cells were pretreated on the apical aspect for $30 \mathrm{~min}$ prior to $4 \mathrm{~h}$ infection with $0.5 \mathrm{ml}$ DMEM containing $0.0001-0.1 \% \mathrm{vol} / \mathrm{vol}$ of either polysorbate- 80 or polysorbate- 60 .

\section{Bacterial translocation across isolated human FAE}

Tissue specimens from macro- and microscopically normal terminal ileum were obtained from patients (eight women and one man, median age 69 (range 36-91) years) who were undergoing surgery for colonic cancer $(\mathrm{N}=3)$ or surveillance colonoscopy for colonic polyps $(\mathrm{N}=6)$; The colon cancer patients had no signs of generalised disease and none had received preoperative chemo- or radiotherapy. All patients had given their informed consent.
Bacterial uptake across ileal FAE and VE was performed in Ussing chambers. ${ }^{31}$ Briefly, tissue mounted in chambers was preincubated for $30 \mathrm{~min}$ with plantain NSP (5 or $50 \mathrm{mg} / \mathrm{ml}$ ) or polysorbate-80 (0.01 or $0.1 \% \mathrm{vol} / \mathrm{vol})$. EGFP-expressing adherent, invasive $E$ coli HM615 was added to the mucosal compartment $\left(1 \times 10^{8} \mathrm{CFU} / \mathrm{ml}\right)$. After $2 \mathrm{~h}$, serosal compartment buffer was sampled and measured at $488 \mathrm{~nm}$ in a fluorimeter. Numbers of bacteria translocated to the serosal compartment were enumerated relative to an EGFP-expressing E coli HM615 standard curve, with confirmation by CFU counting. Transepithelial potential difference (PD) and TEER was monitored throughout. Following Ussing experiments, tissue viability was assessed by adding forskolin $(10 \mu \mathrm{M})$ to the apical chamber, which raises levels of cyclic AMP with resultant active net ion transport in viable tissue (as assessed by an increased short-circuit current). This was followed by histological examination of tissue within each chamber.

\section{Transmission electron microscopy of Caco2-cl1 cells and M-cells}

Following infection, cell monolayers were fixed in $2 \%$ glutaraldehyde and 4\% paraformaldehyde in sterile PBS. Cells were washed with PBS (5 min), twice in PBS/0.15 M glycine and then again in PBS alone. Cells were carefully scraped into microfuge tubes containing PBS, centrifuged at $9000 \mathrm{~g}$ for $2 \mathrm{~min}, 2 \%$ agarose added, centrifuged again, then placed on ice until set. Samples were trimmed to $1 \mathrm{~mm}^{3}$, incubated in $1 \%$ osmium tetroxide for $1 \mathrm{~h}$ at room temperature, followed by sequential dehydration in ethanol and acetone, and mounted in Araldite resin. Sections $(70 \mathrm{~nm})$ were loaded onto copper grids, stained for 5 min each in Reynold's lead citrate and 5\% uranyl acetate, washed in distilled water, air-dried and examined using a FEI $120 \mathrm{kV}$ Tecnai G2 Spirit BioTWIN transmission electron microscope (FEI Company; Hillsboro, OR, USA).

\section{Statistical methods}

$\mathrm{N}$ numbers indicate the total number of independent experiments performed, where each experiment was performed using $\mathrm{n}=3-8$ replicates for any individual treatment group, unless otherwise indicated. For the isolated human tissue experiments, $\mathrm{N}=$ the number of patients. Independent sample groups were assessed for normality and equality of variances. As appropriate, treatment groups were either analysed using the Mann-Whitney $U$ or, for multiple treatment groups, Kruskal-Wallis analysis of variance (ANOVA) was employed, followed by pair-wise comparisons of treatment means (StatsDirect v2.6.2; Sale, UK). Differences were considered significant when $\mathrm{p}<0.05$.

\section{RESULTS}

\section{M-cell generation}

Successful generation of $\mathrm{M}$-cells was confirmed both structurally and functionally. Around $20-70 \%$ of the cells within an 'M-cell' monolayer lacked clearly defined microvilli, while the remainder maintained a structure more closely resembling parent Caco2-cl1 cells (figure 1). Preliminary experiments indicated that co-culture of Caco2-cl1 cells with Raji B cells for 6 days resulted in optimal Mcell generation without significant loss of monolayer integrity, as indicated by a maintained level of TEER throughout the co-culture (figure 1). Cell monolayers where the TEER fell below $300 \Omega \mathrm{cm}^{2}$ at any point during the course of culture were discarded.

Translocation of Salmonella typhimurium and $S$ sonnei (figure $1 \mathrm{G}, \mathrm{H})$ were both confirmed to be significantly higher $(83.3 \pm 12.3$ and 8.6 \pm 1.6 -fold increases (mean \pm SEM); both $\mathrm{p}<0.01 ; \mathrm{N}=3$ ) 
A

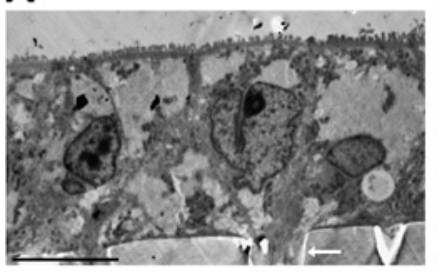

B

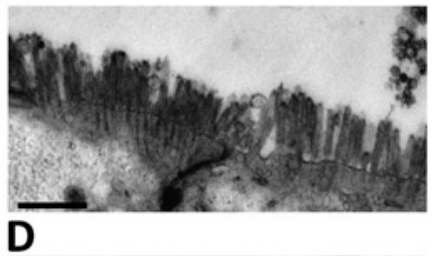

C
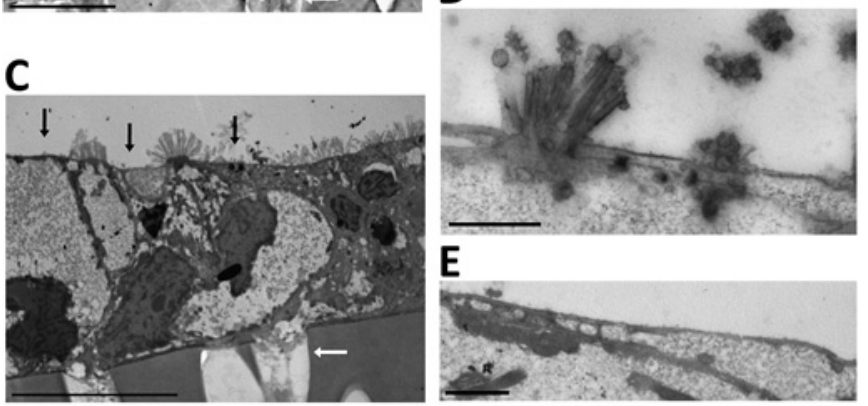

$\mathbf{F}$

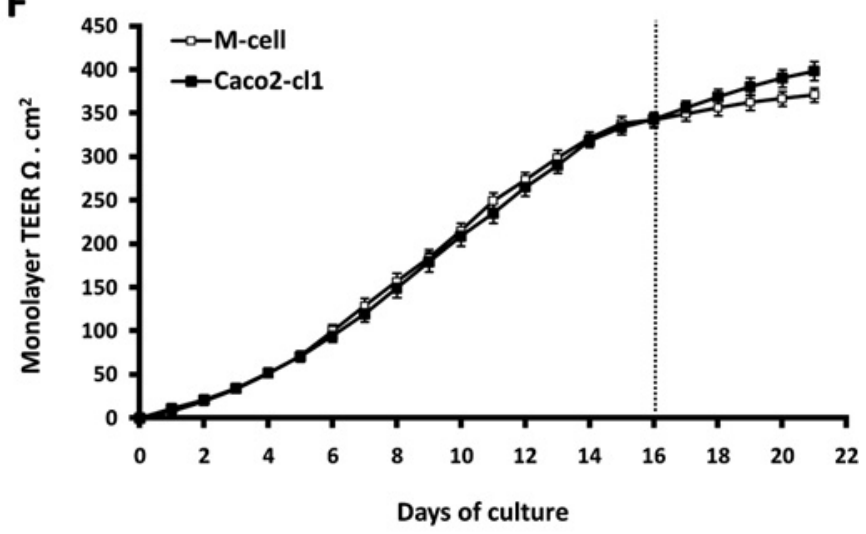

G

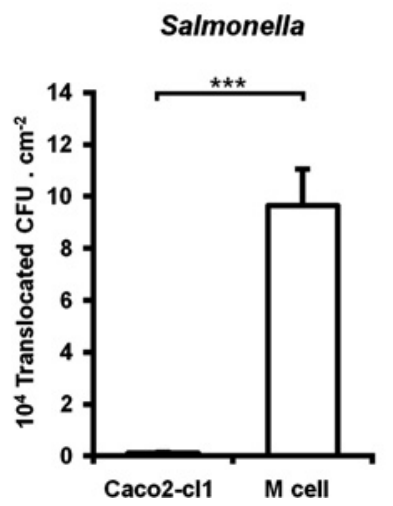

H

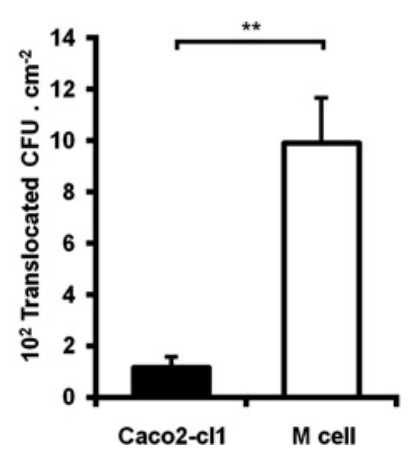

Figure 1 Co-culture model of M-cells. (A) Low power and (B) high power TEM images of representative control Caco2-cl1 monolayers, showing closely packed uniform microvilli on the apical aspect of the cell. (C) Low power and ( $D$ and $E$ ) high power images of in vitro derived M-cells. The M-cells possess an apical surface characteristically devoid of microvilli (indicated by black arrows). In images $(A)$ and $(C)$, the Millicell-PCF filter support can be seen on the lower portion of the image, as can the $3 \mu \mathrm{m}$ pores within the filter (indicated by white arrows). Bar either $10 \mu \mathrm{m}(A$ and $C)$ or $1 \mu \mathrm{m}(B, D$ and $E)$. (F). TEER over time in Caco2-cl1 and M-cell monolayers. Monolayer TEER steadily increases during culture, indicating formation of fully confluent, differentiated monolayers (TEER values in excess of $300 \Omega \mathrm{cm}^{2}$ ). Monolayer incubation with Raji B cells in the lower chamber occurred on day 16 (dashed line) and continued for the following 5 days, leading to the formation of M-cells, while control Caco2-cl1 monolayers formed in the absence of Raji B cells. The TEER of the control Caco2-cl1 monolayers

through Caco2-cl1-Raji B cell co-cultures when compared to Caco2-cl1 cells alone, indicating successful generation of M-like cells.

Crohn's disease and control mucosal $E$ coli translocate across M-cells more readily than across Caco2-cl1 monocultures

Using a representative Crohn's disease mucosa-associated $E$ coli, HM605, ${ }^{6} 1112$ translocation across M-cells was first quantifiable within 15 min post-infection, while translocation across Caco2cl1 monocultures could not be detected until at least 30 min post-infection (figure 2A). All eight Crohn's disease E coli isolates were observed to translocate through $\mathrm{M}$-cells more readily, 15.8-fold median increase (IOR 6.2-32.0; $\mathrm{N}=8$ ) than through Caco2-cl1 monocultures (figure 2B). Translocation of control patient $E$ coli isolates through $\mathrm{M}$-cells was also significantly greater (6.7-fold; IOR 3.7-21.0; $N=5$ ) than that seen through Caco2-c11 cells. Translocation of the $E$ coli $\mathrm{K} 12$, albeit occurring at much lower levels than Crohn's and control patient E coli, was increased 2.3-fold through M-cells (figure 2B), whereas the reference $E$ coli XL-1blue demonstrated minimal ability to translocate via M-cells. Similarly, probiotic E coli Nissle 1917 was translocated less across M-cells than across Caco2-cl1 monolayers (figure $2 \mathrm{~B}$ ).

In all cases, the integrity of cell monolayers was maintained throughout the course of infection as indicated by TEER values $>300 \Omega \mathrm{cm}^{2}$. Translocation of bacteria was not dependent on the TEER; there was no observable correlation between high translocation rates, and lower TEER values, for both $\mathrm{M}$-cells and Caco2-cl1 cells when TEER was in excess of $300 \Omega \mathrm{cm}^{2}$ (Supplementary document S2).

TEM studies, using Crohn's E coli HM605, showed the presence of bacteria within $\mathrm{M}$-cells implying that translocation was transcellular and not paracellular (figure 2C). E coli HM605 was therefore used for the investigation of dose-dependent effects of soluble dietary fibre and emulsifiers on translocation across M-cells in vitro.

E coli translocation across M-cells is inhibited by soluble dietary fibre (non-starch polysaccharides) from plantain and broccoli As per our previous observations in HT29 and I407 cells, ${ }^{6}$ plantain NSP, at both 5 and $50 \mathrm{mg} / \mathrm{ml}$, inhibited $E$ coli adhesion and invasion to the Caco2-cl1 epithelial cell-line used to generate M-cells (Supplementary document S3).

Plantain NSP was also shown to significantly block translocation of Crohn's disease E coli HM605 through M-cells, both at 5 and $50 \mathrm{mg} / \mathrm{mL}$; both $\mathrm{p}<0.01$ ANOVA (figure 3A). Likewise, broccoli NSP significantly inhibited bacterial translocation across $\mathrm{M}$-cells in a dose-dependent manner, at concentrations of $\geq 0.5 \mathrm{mg} / \mathrm{mL}$ (figure $3 \mathrm{~B}$ ). Similar inhibition of translocation of E coli HM605 (albeit at lower bacterial numbers) was seen in Caco2-cl1 monocultures.

Conversely, neither leek NSP (upto $50 \mathrm{mg} / \mathrm{mL}$ ) nor apple NSP, (upto $5 \mathrm{mg} / \mathrm{mL}$ ) had any significant effect upon bacterial translocation across M-cells (figure 3C,D). Apple NSP was not tested at $50 \mathrm{mg} / \mathrm{ml}$, as this concentration resulted in gelling of the NSP. At all concentrations tested, soluble fibre preparations

(Continued)

continued to increase over the following 5 days of incubation (day 16 to 21; solid boxes), as did the TEER of the M-cell monolayers (open boxes), although to a lesser extent ( $n=35$ culture wells for each group).

(G) Salmonella typhimurium and (H) Shigella sonnei show significantly greater translocation through M-cells than through Caco2-cl1 monolayers $(\mathrm{N}=3){ }^{* *}, \mathrm{p}<0.01$ and ${ }^{* *}, \mathrm{p}<0.001$; Mann-Whitney $\mathrm{U}$. 
A

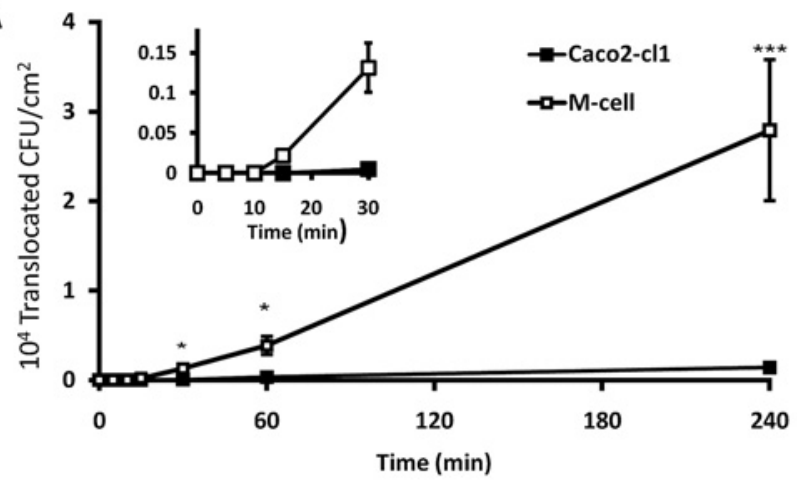

B

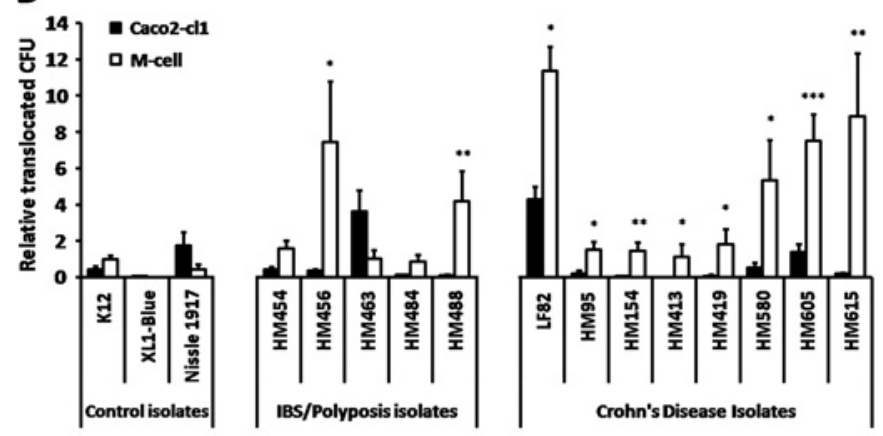

C

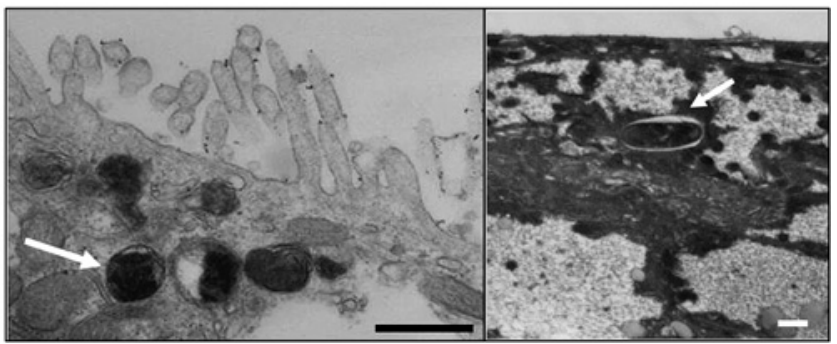

Figure 2 Translocation of human mucosal $E$ coli isolates across Mcells. (A) Translocation across M-cell monolayers was first quantifiable within 15 min post-infection, while translocation across Caco2-cl1 monolayers could not be detected until at least 30 min post-infection. Data presented are for adherent, invasive Crohn's disease $E$ coli HM605. $\left({ }^{*}, \mathrm{p}<0.05\right.$ and ${ }^{* *}, \mathrm{p}<0.001 ;$ ANOVA; $\mathrm{N}=3$ ). (B) Translocation is measured as CFU expressed relative to M-cell translocation of $E$ coli $\mathrm{K} 12$ $(\mathrm{N}=8$, with minimum $\mathrm{n}=8$ replicates for each $E$ coli). Crohn's disease $E$ coli isolates were translocated through $\mathrm{M}$-cell monolayers more readily than through Caco2-cl1 monolayers. Adherent, invasive control patient (irritable bowel syndrome/sporadic polyposis) $E$ coli isolates also translocated through M-cell monolayers more readily, with the exception of isolate HM463. Neither $E$ coli K12 nor $E$ coli XL-1blue showed significantly better translocation through M-cells than through parent Caco2-cl1 cells. Translocation of the probiotic E coli Nissle 1917 was also very low through $\mathrm{M}$-cells, and reduced compared to its translocation through Caco2-cl1 cells. ${ }^{*}, \mathrm{p}<0.05 ;{ }^{* *}, \mathrm{p}<0.01$; and ${ }^{* * *}$, $\mathrm{p}<0.001$; ANOVA. (C) TEM showing the presence of intracellular $E$ coli HM605 within M-cells (white arrows). Intracellular E coli HM605 were not seen within Caco2-cl1 monolayers. Bar $=0.5 \mu \mathrm{m}$.

had no significant effect upon monolayer TEER. No evidence could be found to suggest that fibres could cross the epithelium and directly inhibit bacterial growth. The converse was in fact the case, with plantain NSP significantly enhancing bacterial growth (in a concentration dependant manner) as much as 14.7 ( \pm 0.6$)$-fold at $50 \mathrm{mg} / \mathrm{ml}(\mathrm{n}=4)$, over a $4.5 \mathrm{~h}$ experimental period (inclusive of $30 \mathrm{~min}$ pre-treatment), as determined by culture of the apical Transwell compartment medium.
The inhibitory effect of plantain NSP was observed to be

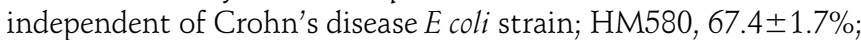

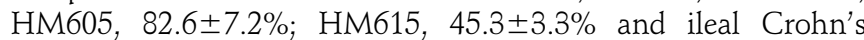
isolate LF82, $61.6 \pm 13.0 \%$ inhibition at $4 \mathrm{~h}$, for $5 \mathrm{mg} / \mathrm{ml}$ plantain NSP; all $\mathrm{p}<0.05$ ) (figure $3 \mathrm{E}$ ). The low level of $\mathrm{M}$-cell translocation seen with non-pathogenic reference $E$ coli $\mathrm{K} 12$ was also inhibited by plantain NSP; $59.0 \pm 11.1 \%, p<0.05$. An inhibitory effect of plantain NSP on translocation of $E$ coli across Caco2-cl1 monocultures was also observed (Supplementary document S4).

\section{$E$ coli translocation across human FAE is inhibited by soluble plantain fibre}

Permeability to EGFP-expressing Crohn's disease E coli HM615 was increased 2-fold across isolated human FAE mounted in Ussing chambers when compared to VE: Histological assessment verified epithelial type in each chamber (figure 4A,B). Translocation of EGFP-E coli HM615 across FAE was seen to be significantly reduced in the presence of plantain NSP, to $45 \pm 7 \%$ (at $5 \mathrm{mg} / \mathrm{ml}$ ) and $27 \pm 7 \%$ (at $50 \mathrm{mg} / \mathrm{ml}$ ) of control levels without plantain treatment $\left(100 \% ; 8.91 \pm 1.8 \times 10^{5}\right.$ bacteria $\left./ \mathrm{ml} / 2 \mathrm{~h}\right)$; both $\mathrm{p}<0.01$ ANOVA, $\mathrm{N}=7$ (figure $4 C$ ). Similarly, plantain NSP reduced $E$ coli translocation across isolated $\mathrm{VE}$, reaching significance at $50 \mathrm{mg} / \mathrm{ml}$ (33 $\pm 9 \%$ reduction) compared to control levels without plantain $\left(100 \% ; \quad 4.37 \pm 0.71 \times 10^{5}\right.$ bacteria/ml/2 h); $\quad \mathrm{p}<0.001$ ANOVA, $\mathrm{N}=9$ (figure 4D). TEER was maintained throughout all experiments. Numbers of bacteria translocated to the serosal compartment were confirmed by overnight culture (figure 4E).

\section{Persistence of plantain non-starch polysaccharides within the gut}

In vitro modelling of fibre breakdown by mixed faecal bacteria obtained from a healthy volunteer (see methods in Supplementary document S5) suggested that $25.4 \pm 8.5 \% \quad(n=4)$ of ingested plantain NSP would be fermented to fatty acids in the human colon within $24 \mathrm{~h}$. Assuming passage of 1 litre of fluid daily into the caecum, intake of $10 \mathrm{~g}$ fibre/day would produce NSP concentrations of 10 and $7.5 \mathrm{mg} / \mathrm{ml}$ in the caecum and rectum respectively. It is of course probable that the latter would also include incompletely degraded fibre components.

\section{$E$ coli translocation is promoted by emulsifiers}

The translocation of Crohn's E coli HM605 across M-cells over $4 \mathrm{~h}$ was significantly increased $(5.3 \pm 2.0$-fold; mean $\pm \mathrm{SD}, \mathrm{N}=5)$ in the presence of $0.1 \% \mathrm{vol} / \mathrm{vol}$ of the permitted food emulsifier polysorbate-80 (figure $5 \mathrm{~A}$ ). A similar action for polysorbate-80 was also observed when using ex vivo human ileal tissue mounted in Ussing chambers. Polysorbate-80, at $0.1 \% \mathrm{vol} / \mathrm{vol}$, significantly enhanced EGFP-expressing $E$ coli HM615 translocation 2 20.2 -fold across human $\operatorname{FAE}(\mathrm{N}=6)$ relative to untreated control; $\mathrm{p}<0.01$ ANOVA, $\mathrm{N}=9$ (figure $5 \mathrm{~B}$ ).

Furthermore, E coli HM605 translocation across Caco2-c11 monocultures was greatly increased (59.3 \pm 33.2 -fold, $\mathrm{N}=5$ ) by addition of polysorbate- 80 into the apical media at a concentration $(0.01 \%)$ 10-fold lower than that needed to increase translocation across $\mathrm{M}$-cells (figure $5 \mathrm{C}$ ). A similar but smaller trend of increased translocation of $E$ coli (2.9 \pm 1.6 -fold) was also observed across isolated VE following pre-treatment with both $0.01 \%$ and $0.1 \%$ polysorbate- $80 ; \mathrm{N}=4$ and $\mathrm{N}=8$ respectively (figure $5 \mathrm{D}$ ).

No disruption to the monolayer integrity, as indicated through maintenance of TEER, was observed with emulsifier concentrations of $\leq 0.1 \% \mathrm{vol} / \mathrm{vol}$, whereas in preliminary experiments, emulsifier concentrations of $\geq 1 \%$ did dramatically decrease TEER and significantly reduce bacterial growth. TEER was maintained throughout all Ussing experiments. 
Figure 3 Plantain NSP blocks translocation of $E$ coli across M-cells in vitro. (A) $E$ coli $\mathrm{HM} 605$ translocation through M-cells is inhibited by the presence of plantain NSP at $5 \mathrm{mg} / \mathrm{ml}$ and $50 \mathrm{mg} / \mathrm{ml}(\mathrm{N}=6)$. (B) Broccoli NSP inhibits bacterial translocation across M-cells at $0.5,5$ and $50 \mathrm{mg} / \mathrm{ml}(\mathrm{N}=3)$. (C) Neither leek NSP nor (D) apple NSP inhibited HM605 translocation across M-cells (both $\mathrm{N}=2$, each at least $\mathrm{n}=5$ replicates). Translocation is measured as CFU expressed relative to M-cell translocation in the absence of fibres. (E) Plantain NSP $(5 \mathrm{mg} / \mathrm{ml})$ inhibits translocation across M-cells for a wide range of $E$ coli $(\mathrm{N}=3)$. Translocation is measured as CFU expressed relative to $\mathrm{M}$-cell translocation of $E$ coli $\mathrm{K} 12$. For all, ${ }^{*}, \mathrm{p}<0.05 ; * *, \mathrm{p}<0.01 ; * * *$, $\mathrm{p}<0.001$; ANOVA.
A

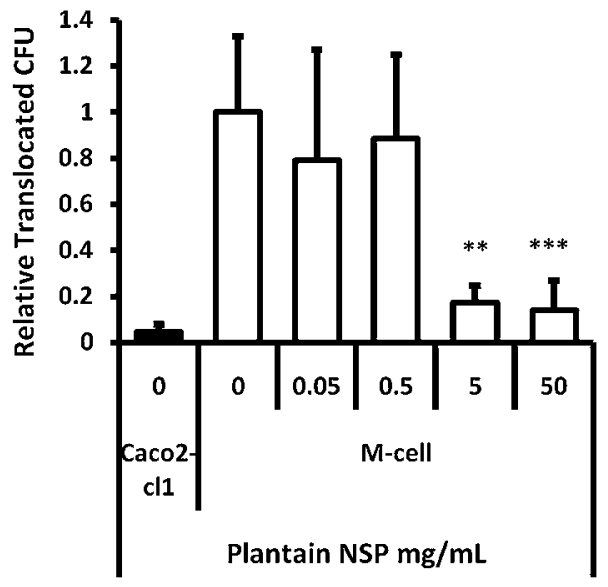

C

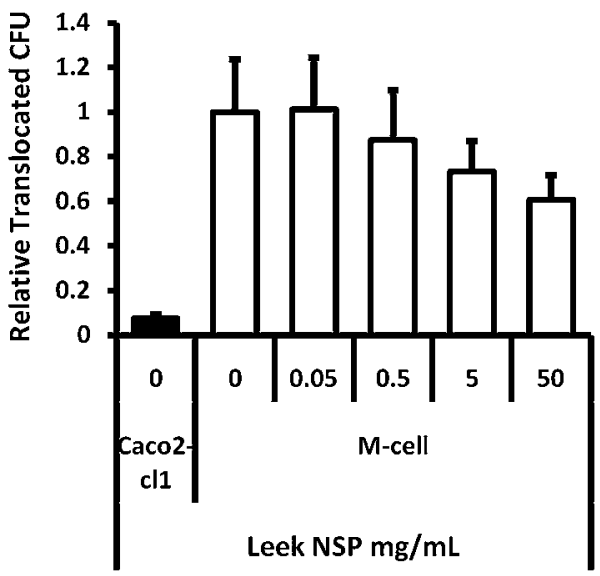

B

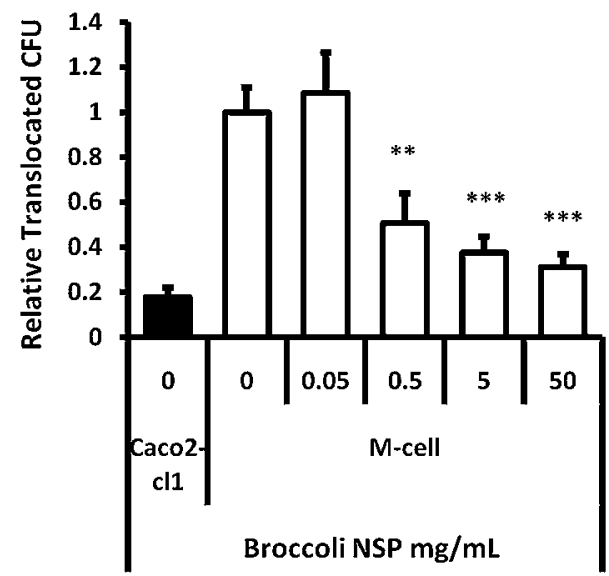

D

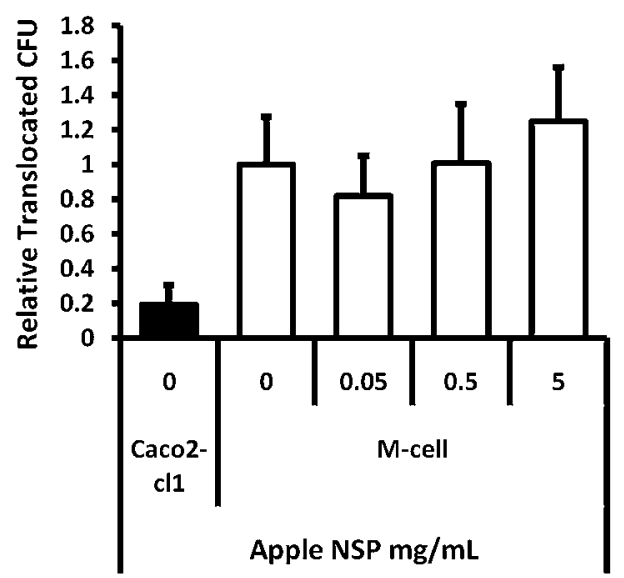

E

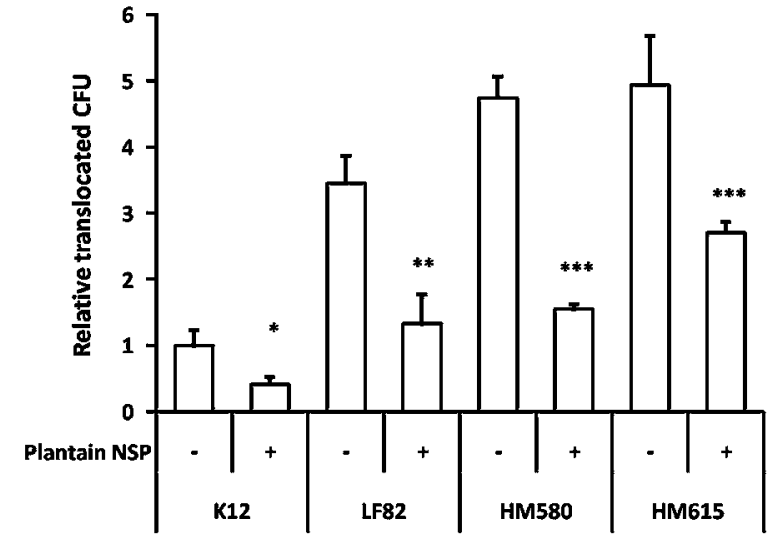

location through parent Caco2-c11 monocultures. TEM confirms the M-cell phenotype with a relative lack of apical microvilli. TEER was maintained throughout all experiments and translocation was clearly shown to be transcellular. $E$ coli isolated from Crohn's mucosae translocated more readily through M-cells than non-IBD and other control $E$ coli, in keeping with their adherent, invasive phenotype. In addition, the epitheliatype specificity for Crohn's $E$ coli was verified in studies on human FAE and VE ex vivo.

Soluble plant fibres, particularly those present in plantain and broccoli, are shown to inhibit translocation of Crohn's mucosaassociated $E$ coli isolates across M-cells, at concentrations that should be readily achievable in vivo. This implies that dietary
This study confirms that Caco2-cl1-derived M-cells can be used to assess translocation of mucosal bacterial isolates and shows the expected, markedly increased, translocation of Salmonella typhimurium and $S$ sonnei in comparison with their trans- 
A

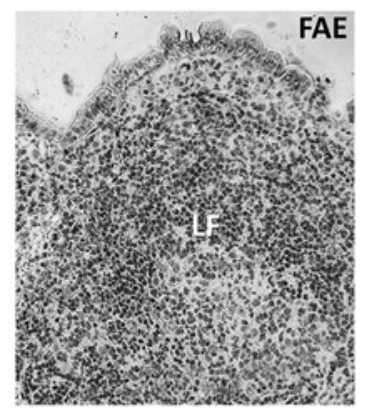

C

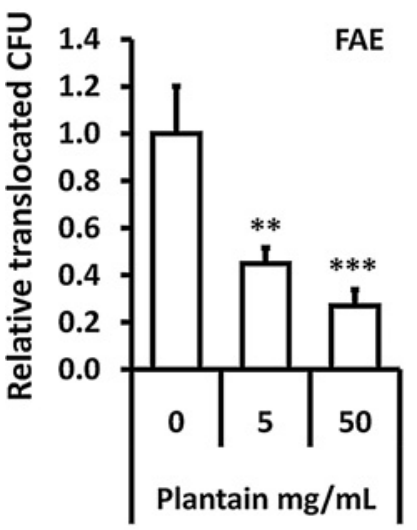

B

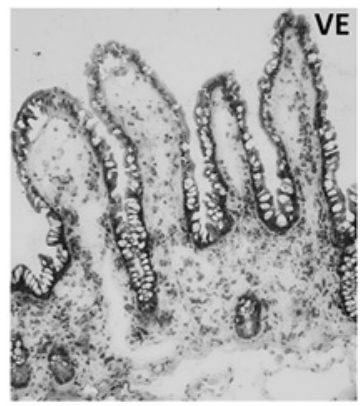

D

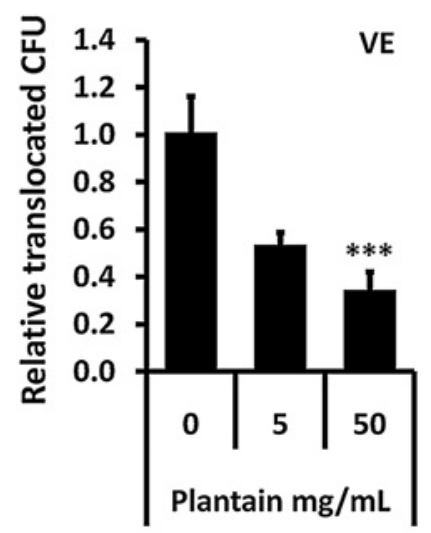

E

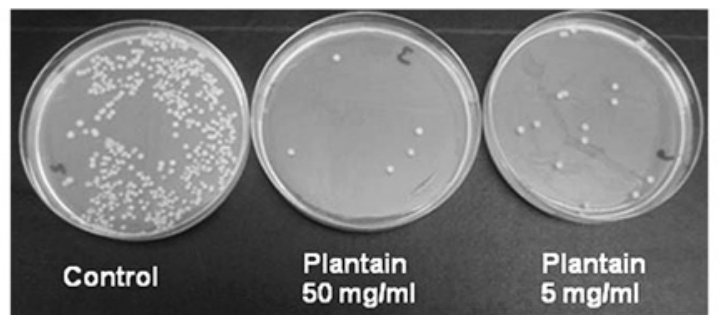

Figure 4 Plantain NSP blocks translocation of $E$ coli across the human intestinal epithelium in Ussing chambers. Histology of (A) an ileal lymphoid follicle (LF) and overlying follicule associated epithelium (FAE) and of (B) villus epithelium (VE) following Ussing chamber experiments. $\times 20$ magnification. ( $C$ and D) EGFP-expressing $E$ coli HM615 translocation through both FAE $(\mathrm{N}=7)$ and $\mathrm{VE}(\mathrm{N}=9)$ and is inhibited by the presence of plantain NSP. ${ }^{* *} \mathrm{p}<0.01 ;{ }^{* *}, \mathrm{p}<0.001$; ANOVA. (E) Overnight culture of Ussing chamber serosal medium following $2 \mathrm{~h}$ translocation of EGFP-expressing $E$ coli HM615 across isolated human epithelium, in the presence and absence of plantain NSP.

supplementation with such fibres might have a protective effect against Crohn's disease relapse by preventing bacterial invasion of the mucosa. NSP from plantain, as from other plant sources, might also have a conventional prebiotic effect via encouragement of probiotic bacteria that would not be relevant to the effects seen in these in vitro models. We feel that the ability of soluble plant fibres to block epithelial attachment and translocation by bacteria may be at least as important as any prebiotic effect, particularly in the small intestine. It also suggests that further investigation is warranted to assess whether soluble dietary fibre might have a more generalised beneficial effect on intestinal health, including bowel cancer and diarrhoeal disease, as a consequence of this ability to block interaction between intestinal bacteria and the epithelium.

The potential importance of M-cells as a portal for bacterial invasion in Crohn's disease is supported by evidence that the initial aphthoid ulcer lesions of Crohn's tend to occur in the

A
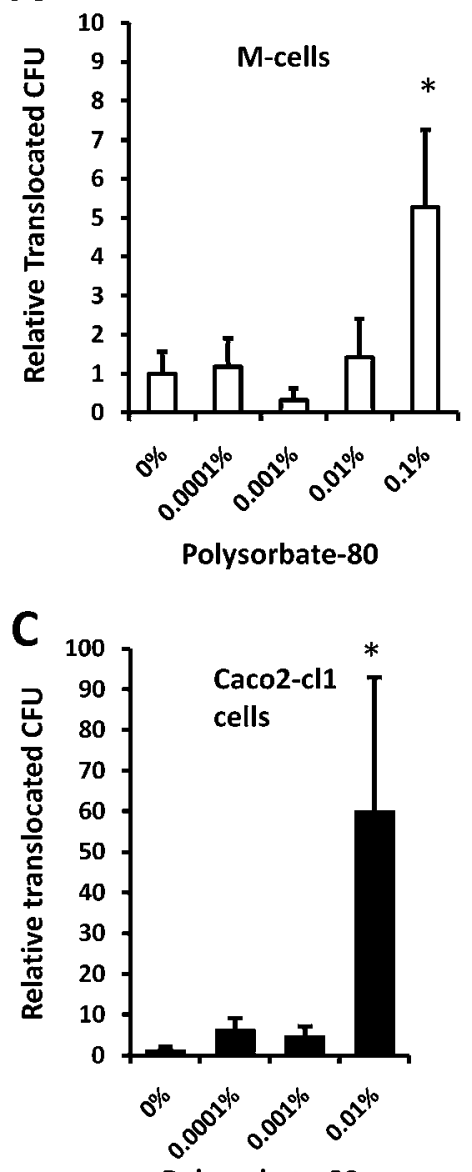

Polysorbate-80
B

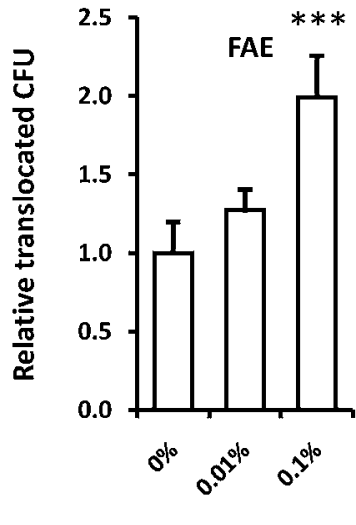

Polysorbate- 80

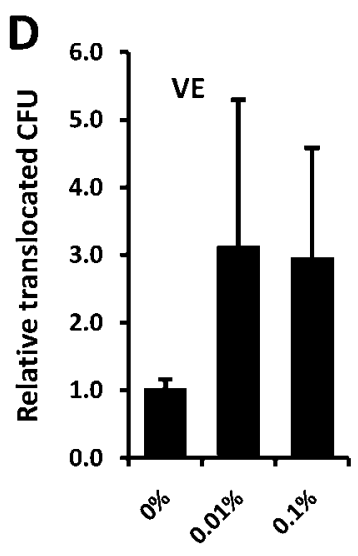

Polysorbate-80

Figure 5 Dietary emulsifier polysorbate- 80 increases translocation of $E$ coli across the intestinal epithelium. Polysorbate- 80 increased translocation of Crohn's disease $E$ coli across both (A) M-cells and (B) human follicle-associated epithelium (FAE). Similarly, polysorbate-80 enhanced translocation of $E$ coli across (C) parent Caco2-cl1 cells and (D) human villus epithelium (VE). ${ }^{*}, \mathrm{p}<0.05 ;{ }^{* *}, \mathrm{p}<0.01$; ANOVA ( $\mathrm{N}=4-8$ ). Crohn's $E$ coli HM605 and EGFP-expressing HM615 were used for the in vitro and ex vivo epithelium translocation studies respectively.

mucosa overlying PP in the distal ileum and lymphoid follicles in the colon. ${ }^{16} 3233$ Indeed, ex vivo work conducted with macroscopically normal Crohn's disease FAE biopsies show increased numbers of adherent non-pathogenic $E$ coli compared to controls. ${ }^{34}$ Chronic stress has been shown in rats to lead to increased passage of $E$ coli K12 across FAE, but not VE. ${ }^{35}$

The effect of food emulsifiers on $E$ coli translocation provides another potential explanation for the association between the modern 'Western' diet and Crohn's pathogenesis. Polysorbate-80 at $0.1 \% \mathrm{vol} / \mathrm{vol}$, led to 5 -fold increased translocation across M-cells and a doubled translocation across human FAE. At the lower concentration of $0.01 \%$, a 59 -fold increase in translocation across Caco2-cl1 cells was observed, both without any negative effect on monolayer TEER. Based on the acceptable daily intake of $25 \mathrm{mg} / \mathrm{kg}$ polysorbate- 80 to body weight, ${ }^{36}$ this concentration of $0.01 \%$ would represent a persistence of $6.7 \%$ into the terminal ileum of a typical $60 \mathrm{~kg}$ human, assuming 1 litre of intestinal contents per day passing to the caecum. Previous studies in healthy human volunteers have shown $5 \%$ urinary excretion of the polyoxyethylene portion of orally ingested polysorbate- $80 .{ }^{37}$ It is not known to what extent the polysorbate ester, which is split by pancreatic lipase, might pass through to the terminal 
ileum. Polysorbate- 80 has been shown to integrate within cell membranes $^{28}$ resulting in a change of membrane microviscosity. ${ }^{29}$ It is possible that alterations in the membrane fluidity could alter bacterial adhesion and translocation through epithelial cells. The data presented here indicate that Caco2-cl1 cells are more susceptible to the effects of polysorbate- 80 than $\mathrm{M}$-cells, and that both cell types are more susceptible to the effects of polysorbate- 80 than polysorbate-60. The increase in bacterial translocation across the parent Caco2-cl1 cells, although less relevant to invasion via PP or lymphoid follicles, might imply a greater risk of bacterial mucosal invasion at other sites. In the small intestine, unlike the colon, the mucus layer is not continuous ${ }^{38}$ and the epithelium will be relatively exposed to emulsifiers. The effects of emulsifiers may have important implications for treatment of Crohn's disease, particularly in view of the increased permeability that is already known to exist in this condition. Enteral nutritional feeding with elemental or whole protein feed is often used as either primary or adjuvant therapy for Crohn's disease. ${ }^{4}$ All enteral feeds that are ready mixed as a liquid and contain lipid, contain emulsifers. The emulsifier used will vary from feed to feed. We have previously commented that the varying response to Crohn's disease of different enteral feeds might relate to their emulsifier content ${ }^{39}$ and are currently exploring the possible epidemiological association between inflammatory bowel disease and emulsifier consumption.

These studies show that different dietary components may have powerful and contrasting effects on bacterial translocation across intestinal $\mathrm{M}$-cells. These effects may be relevant to the role of environmental factors in the pathogenesis of Crohn's disease and suggest possible novel therapeutic approaches.

Acknowledgements Adherent, invasive $E$ coli LF82 was a gift from Professor Arlette Darfeuille-Michaud, Université Auvergne Clermont-1, Clermont-Ferrand F-63001, France. The authors are extremely grateful for support from Drs lan Prior and Connie Muncke of the Electron Microscopy Unit, Biomedical Sciences, University of Liverpool. The authors also wish to thank Mrs Ylva Braaf for skilful technical assistance in the Linköping Ussing laboratory.

Funding CLR was supported by the Wellcome Trust 4 year $\mathrm{PhD}$ programme in Cellular and Molecular Physiology (074949/Z/04/Z). Further support to BJC and JMR was provided by the National Institute for Health Research (NIHR) Specialist Biomedical Research Centre for Microbial Diseases, Liverpool (01CD1) and the National Association for Colitis \& Crohn's disease (M/08/1). Translocation studies using human tissues were funded by a grant to JDS from the Swedish Research Council (VR-M). Other funders: Wellcome Trust; NIHR, MRC, NACC, Swedish Research Council.

Competing interests $\mathrm{JMR}$ is a past/present member of advisory boards for Procter \& Gamble, Schering-Plough, Chiesi, Falk and Celltech. With the University of Liverpool and Provexis PIC (UK), JMR holds a patent for use of a soluble fibre preparation as therapy for Crohn's disease. NO'K is an employee of Provexis Plc.

Ethics approval This study was conducted with the approval of the Regional Human Ethics Committee; Linköping, Sweden.

Contributors BJC, CLR, JDS and JMR designed the research and obtained funding; CLR, AVK and SHD performed experiments; BJC, CLR, JMR, NO'K, AVK, JDS and SHD performed analysis and interpretation of data; NO'K provided material support; BJC, CLR and JMR wrote the manuscript.

Provenance and peer review Not commissioned; externally peer reviewed.

\section{REFERENCES}

1. Lees CW, Satsangi J. Genetics of inflammatory bowel disease: implications for disease pathogenesis and natural history. Expert Rev Gastroenterol Hepatol 2009:3:513-34

2. Cottone M, Rosselli M, Orlando A, et al. Smoking habits and recurrence in Crohn's disease. Gastroenterology 1994;106:643-8.

3. Yao T, Matsui T, Hiwatashi N. Crohn's disease in Japan: diagnostic criteria and epidemiology. Dis Colon Rectum 2000;43:S85-93.

4. Akobeng AK, Thomas AG. Enteral nutrition for maintenance of remission in Crohn's disease. Cochrane Database Syst Rev 2007;(3):CD005984.
5. Knight $\mathbf{P}$, Campbell BJ, Rhodes JM. Host-bacteria interaction in inflammatory bowel disease. Br Med Bull 2008;88:95-113.

6. Martin HM, Campbell BJ, Hart CA, et al. Enhanced Escherichia coli adherence and invasion in Crohn's disease and colon cancer. Gastroenterology 2004:127:80-93.

7. Swidsinski A, Khilkin M, Kerjaschki D, et al. Association between intraepithelial Escherichia coli and colorectal cancer. Gastroenterology 1998;115:281-6.

8. Darfeuille-Michaud A. Adherent-invasive Escherichia coli: a putative new E. coli pathotype associated with Crohn's disease. Int J Med Microbiol 2002;292:185-93.

9. Boudeau J, Glasser AL, Masseret $\mathrm{E}$, et al. Invasive ability of an Escherichia coli strain isolated from the ileal mucosa of a patient with Crohn's disease. Infect Immun 1999;67:4499-509.

10. Glasser AL, Boudeau J, Barnich N, et al. Adherent invasive Escherichia coli strains from patients with Crohn's disease survive and replicate within macrophages without inducing host cell death. Infect Immun 2001:69:5529-37.

11. Subramanian S, Roberts CL, Hart CA, et al. Replication of colonic Crohn's disease mucosal Escherichia coli isolates within macrophages and their susceptibility to antibiotics. Antimicrob Agents Chemother 2008:52:427-34.

12. Subramanian S, Rhodes JM, Hart CA, et al. Characterization of epithelial IL-8 response to inflammatory bowel disease mucosal $E$. coli and its inhibition by mesalamine. Inflamm Bowel Dis 2008:14:162-75.

13. Meconi S, Vercellone A, Levillain F, et al. Adherent-invasive Escherichia coli isolated from Crohn's disease patients induce granulomas in vitro. Cell Microbiol 2007:9:1252-61

14. Ryan P, Kelly RG, Lee G, et al. Bacterial DNA within granulomas of patients with Crohn's disease-detection by laser capture microdissection and PCR. Am J Gastroenterology 2004;99:1539-43.

15. Liu Y, van Kruiningen HJ, West AB, et al. Immunocytochemical evidence of Listeria Escherichia coli, and Streptococcus antigens in Crohn's disease. Gastroenterology 1995; 108:1396-404.

16. Fujimura Y, Kamoi R, lida M. Pathogenesis of aphthoid ulcers in Crohn's disease: correlative findings by magnifying colonoscopy, electron microscopy, and immunohistochemistry. Gut 1996;38:724-32.

17. Rickert RR, Carter HW. The "early" ulcerative lesion of Crohn's disease: correlative light- and scanning electron-microscopic studies. J Clin Gastroenterol 1980:2:11-19.

18. Owen RL, Jones AL. Epithelial cell specialization within human Peyer's patches: an ultrastructural study of intestinal lymphoid follicles. Gastroenterology 1974:66:189-203.

19. Neutra MR. M cells in antigen sampling in mucosal tissues. Curr Top Microbiol Immunol 1999:236:17-32.

20. Secott TE, Lin TL, Wu CC. Mycobacterium avium subsp. paratuberculosis fibronectin attachment protein facilitates $\mathrm{M}$-cell targeting and invasion through a fibronectin bridge with host integrins. Infect Immun 2004:72:3724-32.

21. Jensen VB, Harty JT, Jones BD. Interactions of the invasive pathogens Salmonella typhimurium, Listeria monocytogenes, and Shigella flexneri with $\mathrm{M}$ cells and murine Peyer's patches. Infect Immun 1998;66:3758-66.

22. Owen RL, Pierce NF, Apple RT, et al. M cell transport of Vibrio cholerae from the intestinal lumen into Peyer's patches: a mechanism for antigen sampling and for microbial transepithelial migration. J Infect Dis 1986;153:1108-18.

23. Blanco LP, DiRita VJ. Bacterial-associated cholera toxin and GM1 binding are required for transcytosis of classical biotype Vibrio cholerae through an in vitro $\mathrm{M}$ cell model system. Cell Microbiol 2006;8:982-98.

24. Silva MA. Intestinal dendritic cells and epithelial barrier dysfunction in Crohn's disease. Inflamm Bowel Dis 2009:15:436-53.

25. Sugano M. Characteristics of fats in Japanese diets and current recommendations Lipids 1996;31(Suppl):S283-6.

26. Freel RW, Hatch $\mathrm{M}$, Earnest $\mathrm{DL}$, et al. Role of tight-junctional pathways in bile saltinduced increases in colonic permeability. Am J Physiol 1983;245:G816-23.

27. Dimitrijevic D, Shaw AJ, Florence AT. Effects of some non-ionic surfactants on transepithelial permeability in Caco-2 cells. J Pharm Pharmacol 2000;52:157-62.

28. Zordan-Nudo T, Ling V, Liu Z, et al. Effects of nonionic detergents on P-glycoprotein drug binding and reversal of multidrug resistance. Cancer Res 1993:53:5994-6000.

29. Friche $\mathbf{E}$, Jensen PB, Sehested M, et al. The solvents cremophor EL and Tween 80 modulate daunorubicin resistance in the multidrug resistant Ehrlich ascites tumor. Cancer Commun 1990:2:297-303.

30. Rescigno $\mathbf{M}$, Urbano $\mathbf{M}$, Valzasina $B$, et al. Dendritic cells express tight junction proteins and penetrate gut epithelial monolayers to sample bacteria. Nat Immunol 2001:2:361-7.

31. Keita AV, Gullberg E, Ericson AC, et al. Characterisation of antigen and bacterial transport in the follicle-associated epithelium of human ileum. Lab Invest 2006;86:504-15

32. Fujimura $\mathbf{Y}$, Hosobe $M$, Kihara T. Ultrastructural study of $M$ cells from colonic lymphoid nodules obtained by colonoscopic biopsy. Dig Dis Sci 1992;37:1089-98.

33. Shikuwa S, Isomoto $H$, Mizuta $Y$, et al. Magnifying videoendoscopic findings of Peyer's patches in the terminal ileum of Crohn's disease. Gut 2007:56:894-5.

34. Keita AV, Salim SY, Jiang T, et al. Increased uptake of non-pathogenic E. coli via the follicle-associated epithelium in longstanding ileal Crohn's disease. J Pathol 2008;215:135-44.

35. Velin AK, Ericson AC, Braaf $Y$, et al. Increased antigen and bacterial uptake in follicle associated epithelium induced by chronic psychological stress in rats. Gut 2004:53:494-500.

36. Food and Agriculture Organisation/World Health Organisation (FAO/WHO) Expert Committee on Food Additives. Toxicological evaluation of some food 
additives including anticaking agents, antimicrobial, antioxidants, emulsifiers and thickening agents. WHO Food Additives Sedrioes 1974;5:254-63.

37. Culver PJ, Wilcox CS, Jones CM, et al. Intermediary metabolism of certain polyoxyethylene derivatives in man. I. Recovery of the polyoxyethylene moiety from urine and faces following ingestion of polyoxyethylene (40) mono-stearate. J Pharmacol Exp Ther 1951:103:377-81.
38. Atuma C, Strugala V, Allen A, et al. The adherent gastrointestinal mucus gel layer: thickness and physical state in vivo. Am J Physiol Gastrointest Liver Physiol 2001;280:G922-9.

39. Leiper K, Woolner J, Mullan MM, et al. A randomised controlled trial of high versus low long chain triglyceride whole protein feed in active Crohn's disease. Gut 2001;49:790-4.

\section{Editor's quiz: Gl snapshot}

\section{An unusual cause of anaemia}

\section{CLINICAL PRESENTATION}

A 64-year-old gentleman presented to the emergency department with an episode of angioneurotic oedema ascribed to Valsartan and was noted to have iron deficiency anaemia. He had undergone cardiac transplantation in 1999 and subsequently developed several skin cancers (squamous cell carcinomas and a melanoma removed by the plastic surgeons). Two years prior to this presentation he had been diagnosed with a T3N2 M0 non-small cell lung cancer treated with radiotherapy. The patient was discharged with a plan for outpatient CT study, gastroscopy and colonoscopy but before these were performed, he was re-admitted with symptomatic anaemia. CT examination showed a $9 \mathrm{~cm}$ mass arising from the small bowel. Percutaneous biopsy was performed under ultrasound guidance.

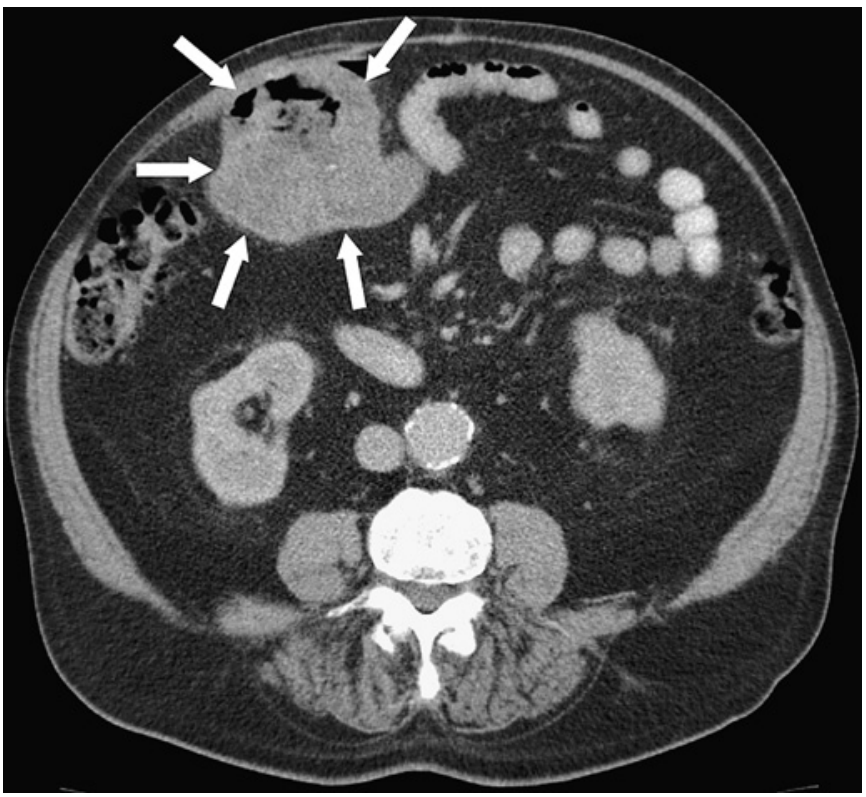

Figure 1 Abdominal CT image with intravenous contrast. There is a large mass measuring $9 \mathrm{~cm}$ diameter with air and fluid centrally, related to the small bowel. The mass is thick walled and closely applied to the anterior abdominal wall.

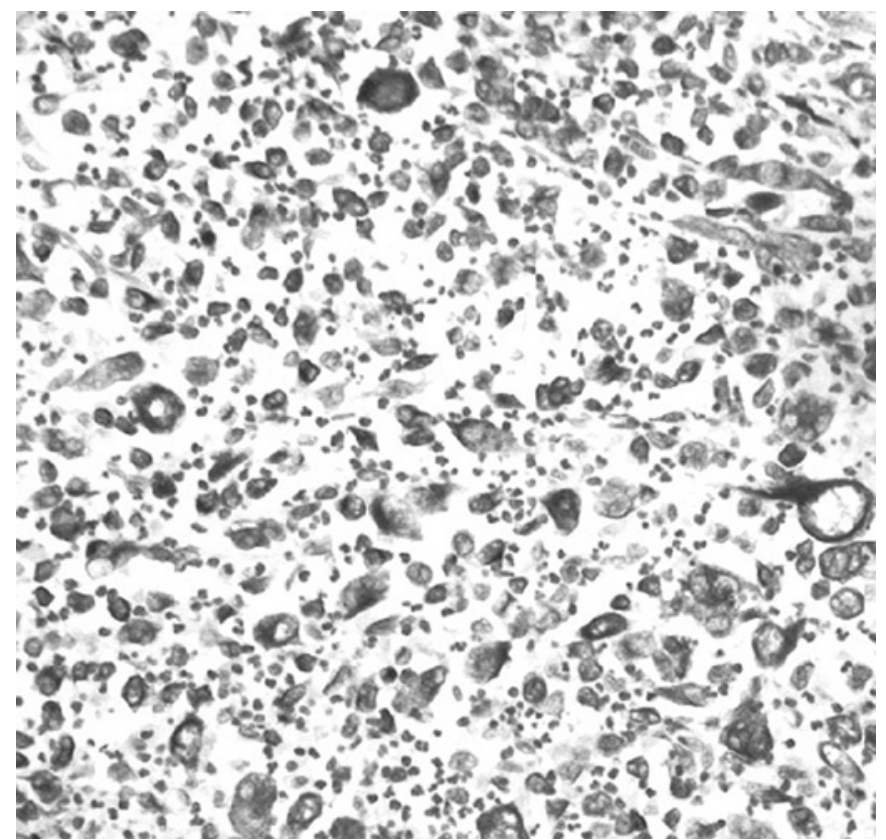

Figure 2 Core biopsy sample CK7 immunohistochemistry. There is severe pleomorphism with multinucleate giant cell formation. Mitotic activity is noted, including several highly atypical forms. There is a prominent associated mixed inflammatory cell infiltrate.

\section{QUESTION}

What is the diagnosis and how was it treated?

See page 1388 for the answer

\section{Alan P Wiles, ${ }^{1}$ David J Lomas, ${ }^{3}$ Justin Davies, ${ }^{4}$ Vicki Save, Ewen AB Cameron ${ }^{2}$}

${ }^{1}$ Department of Gastroenterology, Hinchingbrooke Hospital, Hinchingbrooke Park Huntingdon, UK: ${ }^{2}$ Department of Gastroenterology, Addenbrooke's Hospital, Hills Road, Cambridge, UK; ${ }^{3}$ Department of Radiology, Addenbrooke's Hospital, Hills Road Cambridge, UK; ${ }^{4}$ Department of General Surgery, Addenbrooke's Hospital,

Hills Road, Cambridge, UK; ${ }^{5}$ Department of Pathology, Royal Infirmary of Edinburgh, Edinburgh UK

Correspondence to Dr Alan P Wiles, Department of gastroenterology, Hinchingbrooke Hospital, Hinchingbrooke park, Huntingdon PE29 6NT, UK ; Alan.p.wiles@btopenworld.com

Competing interests None.

Patient consent Obtained.

Provenance and peer review Not commissioned; externally peer reviewed

Published Online First 10 June 2010

Gut 2010;59:1339. doi:10.1136/gut.2009.182220 